\title{
Hemodynamic and inotropic effects of endothelin-1 in vivo*
}

\author{
M. E. Beyer ${ }^{1}$, S. Nerz $^{1}$, B. K. Krämer ${ }^{2}$, and H. M. Hoffmeister ${ }^{1}$ \\ ${ }^{1}$ Medizinische Klinik, Abt. III, Eberhard-Karls-Universität, Tübingen, and \\ ${ }^{2}$ Medizinische Klinik, Abt. II, Universität Regensburg, FRG
}

Summary: Endothelin-1 (ET-1) is known to have strong vasoactive properties. Contradictory results have been reported with regard to its inotropic effects.

This study examined the dose-dependent $(500,1000,2500,5000$ and $10000 \mathrm{ng} \mathrm{ET}-1 / \mathrm{kg}$ vs. $\mathrm{NaCl}$ controls) hemodynamic and inotropic effects of ET-1 in 53 open-chest rats during and after a 7-min infusion. Besides measurements in the intact circulation the myocardial function was examined by isovolumic registrations independent of peripheral vascular effects.

A transient ET-1 induced $(500,1000,2500,5000 \mathrm{ng}$ ET-1/kg) decrease of the left ventricular systolic pressure (LVSP) and the mean aortic pressure $\left(\mathrm{AoP}_{\text {mean }}\right)$ was followed by a dose-related rise of these pressures (LVSP: $-1 \%,-1 \%,+8 \%,+16 \%$ vs. preinfusion values; $\mathrm{AoP}_{\text {mean }}:-11 \%,+9 \%,+39 \%$, $+52 \%$ ). Heart rate (HR) was not influenced by ET-1. Due to the dose-dependent decrease of the stroke volume (SV) the cardiac output (CO) was reduced (CO: $-8 \%,-23 \%,-40 \%,-50 \%)$. After an initial vasodilatation ET-1 elevates the total peripheral resistance (TPR: $-1 \%,+49 \%,+139 \%$, $+215 \%$ ) dose-dependently. $10000 \mathrm{ng}$ ET- $1 / \mathrm{kg}$ was a lethal dose resulting in cardiac failure within minutes (low output). Since the maximum of the isovolumic LVSP (peak LVSP) and the corresponding $\mathrm{dP} / \mathrm{dt}_{\text {max }}$ (peak $\mathrm{dP} / \mathrm{dt}_{\max }$ ) were unchanged under ET-1, the isovolumic measurements do not indicate a positive inotropic effect of ET-1 in vivo in contrast to published results of in vitro experiments.

It may be possible that a direct positive inotropic effect of ET-1 observed in in vitro studies is counterbalanced in vivo by an indirect negative inotropic effect due to the coronar-constrictive effect of ET-1.

Key words: Endothelin-1 - hemodynamic effects - inotropic effects - isovolumic measurements - rats

\section{Introduction}

Endothelin-1 is a 21 -amino acid peptide that was originally purified from porcine aortic endothelial cells (38). Endothelin-1 is the most potent vasoconstrictor known to date. Its strong and sustained vasoconstrictive activity can be explained by the fact that endothelin- 1 increases the intracellular $\mathrm{Ca}^{2+}$ concentration in smooth muscle cells (34, $35)$. The receptor-mediated endothelin-induced rise in cytosolic $\mathrm{Ca}^{2+}$ is, on the one hand, the result of an enhanced influx of extracellular $\mathrm{Ca}^{2+}$ through indirectly-activated calcium channels (34); on the other hand, endothelin-1 causes a phospholipase Cmediated release of intracellular $\mathrm{Ca}^{2+}$ from the sarcoplasmatic reticulum (15) and an indirect activation of the $\mathrm{Na}^{+}-\mathrm{Ca}^{2+}$ exchanger (33).

Such an endothelin-induced increase of cytosolic $\mathrm{Ca}^{2+}$ was also described in cardiac myocytes $(10,14)$. Indeed, in vitro experiments on cardiac tissues showed a positive

\footnotetext{
* Parts of the results were presented at the 13th European Section Meeting of the International Society for Heart Research, Heidelberg, FRG, 1992
} 
inotropic effect of endothelin-1 $(12,14,17,22,26,37)$, which can also be explained in part by an endothelin-induced sensitization of cardiac myofilaments to intracellular $\mathrm{Ca}^{2+}$ due to stimulation of the sarcolemmal $\mathrm{Na}^{+}-\mathrm{H}^{+}$exchanger (22). However, the results with regard to myocardial effects have been controversial in isolated working hearts $(2,17)$ and in intact animals $(19,39)$, probably due to the vasoconstrictive action of endothelin-1 (which was overcome in some in vitro heart studies).

The present study was initiated to investigate the dose-dependent hemodynamic and especially the inotropic effects of endothelin-1 in vivo in an open-chest animal model, which permits besides hemodynamic measurements in the intact circulation also the determination of myocardial effects independent of peripheral vascular effects by isovolumic measurements (11).

\section{Methods}

The study was performed on 4-month-old normotensive male Wistar rats $(n=53$; weight $399 \pm 6 \mathrm{~g}$ (mean $\pm \mathrm{SEM})$ ). After anesthesia with urethane $50 \%(2.5 \mathrm{ml} / \mathrm{kg}$ body weight) intraperitoneally, a venous line for drug infusion was established through the right jugular vein. An ECG (lead II) was recorded to measure the heart rate (HR). A median sternotomy was performed under artificial ventilation with room air (Starling respirator, Braun, Melsungen, FRG). The heart and the great vessels were exposed and the pericardium was opened. A flexible plastic tube advanced through the left carotid artery to the aortic arch was connected to a fluid-filled (heparinized saline) pressure transducer (Statham P23 ID, Gould, Oxnard, CA, USA) to register the aortic blood pressure. To record the left ventricular pressure (LVP) a short fluid-filled 18 gauge metal cannula, positioned through the apex in the left ventricle, was connected to a fluid-filled pressure transducer (Senso Nor 840, Horten, Norway). This transducer was also connected to an amplifier (type 806, Siemens, Munich, FRG) for reading of the left ventricular end-diastolic pressure (LVEDP) and to a differentiator (type 868, Siemens) to calculate the first derivate of the LVP (dP/dt). An electromagnetic flow probe (ID $2 \mathrm{~mm}$, BL 620 Flowmeter, Biotronix, Kensington, MD, USA) was fitted around the ascending aorta to register stroke volume (SV; except for coronary flow).

$\mathrm{ECG}$, the flow signal, the aortic pressures $\left(\mathrm{AoP}_{s}, \mathrm{AoP}_{d}\right)$, the left ventricular systolic pressure (LVSP), LVEDP and $\mathrm{dP} / \mathrm{dt}_{\text {max }}$ were recorded on a multichannel ink jet recorder (Mingograf 803, Siemens-Elema, Sweden). The mean aortic pressure $\left(A o P_{m}=\left(2 \times A_{o P}+A o P_{s}\right) / 3\right), S V$ (planimetry of the phasic flow signal, mean of three consecutive beats), cardiac output $(\mathrm{CO}=\mathrm{SV} \times \mathrm{HR})$ and the total peripheral resistance $\left(\mathrm{TPR}=\mathrm{AoP}_{\mathrm{m}} / \mathrm{CO}\right)$ were then derived. Besides hemodynamic measurements in the intact circulation the myocardial function was examined by isovolumic measurements independently of circulatory changes by cross-clamping the ascending aorta until the maximum of the isovolumic LVSP (peak LVSP) was obtained. From the beat with the highest isovolumic LVSP, the peak $\mathrm{dP} / \mathrm{dt}_{\max }$ and peak LVEDP were determined. The peak LVSP and the corresponding peak $\mathrm{dP} / \mathrm{dt}_{\max }$ are indices of myocardial contractility independent of peripheral vascular effects. At the end of the experiments the pressure-volume relation of the left ventricle was measured as described previously in detail (11). Because the pressure-volume relation was not influenced by endothelin1 , the left ventricular end-diastolic volume (LVEDV) can be derived for a given LVEDP from the pressure-volume relation. 


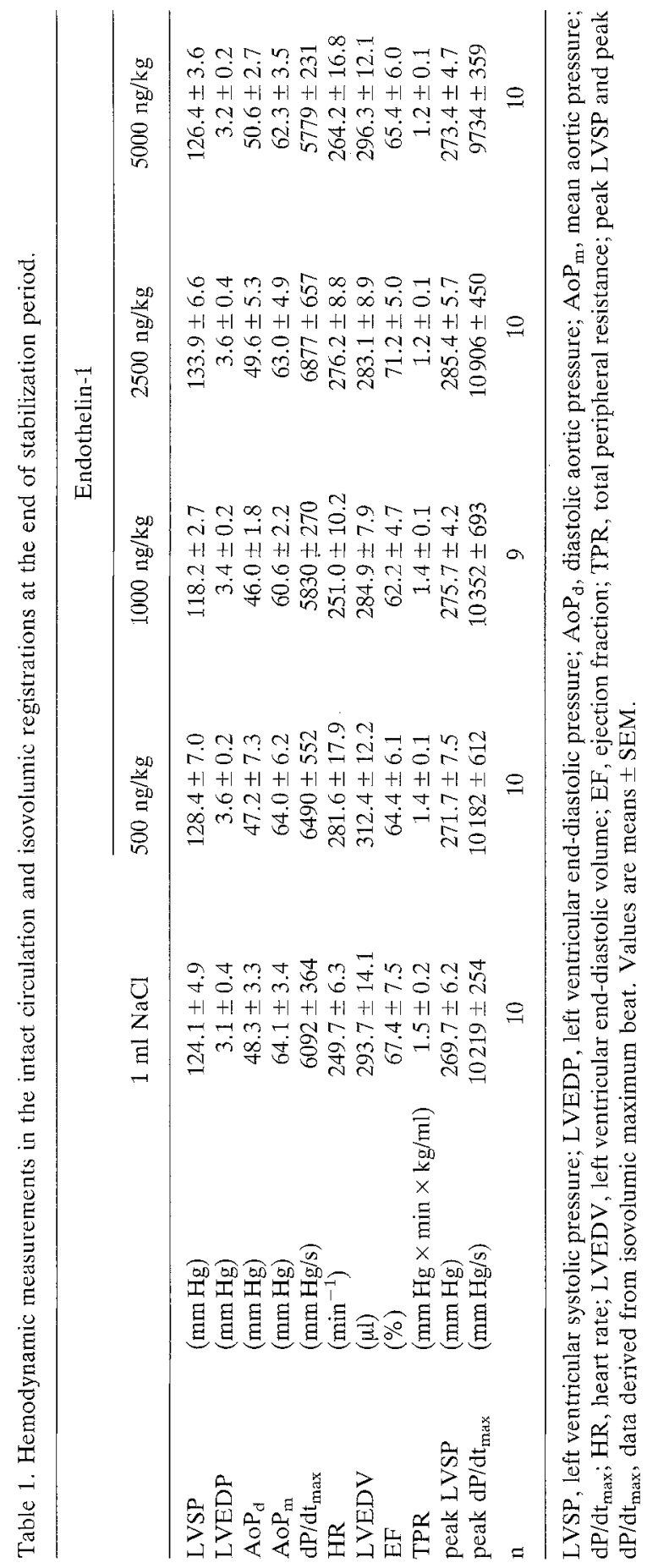


Endothelin-1 was dissolved in a final volume of $1 \mathrm{ml}$ and infused in 7 min with a precision pump (Braun, Melsungen, FRG). To investigate the dose-dependent effects of endothelin-1, we administered doses of $500 \mathrm{ng} / \mathrm{kg}(\mathrm{n}=10), 1000 \mathrm{ng} / \mathrm{kg}(\mathrm{n}=9), 2500$ $\mathrm{ng} / \mathrm{kg}(\mathrm{n}=10), 5000 \mathrm{ng} / \mathrm{kg}(\mathrm{n}=10)$, and $10000 \mathrm{ng} / \mathrm{kg}(\mathrm{n}=4)$ endothelin- 1 . The control group $(\mathrm{n}=10)$ received $1 \mathrm{ml} 0.9 \% \mathrm{NaCl}$ solution. Endothelin-1 was obtained from Sigma (Sigma, St. Louis, MO, USA). Preinfusion control data of auxotonic and isovolumic measurements were obtained after a $15-\mathrm{min}$ stabilization period. Three minutes after these measurements were made the drug infusion was started. Auxotonic measurements were recorded every minute until termination of the infusion and 5, 10

Table 2. Hemodynamic measurements in the intact circulation and isovolumic registrations at termination of infusion and at 5 and 15 min after infusion.

Endothelin-1

\begin{tabular}{|c|c|c|c|c|c|c|}
\hline & & \multirow[b]{2}{*}{$1 \mathrm{ml} \mathrm{NaCl}$} & \\
\hline & & & $500 \mathrm{ng} / \mathrm{kg}$ & $1000 \mathrm{ng} / \mathrm{kg}$ & $2500 \mathrm{ng} / \mathrm{kg}$ & $5000 \mathrm{ng} / \mathrm{kg}$ \\
\hline LVSP & $\begin{array}{c}7^{\prime} \text { inf. } \\
5^{\prime} \text { post. } \\
15^{\prime} \text { post. }\end{array}$ & $\begin{array}{r}105.9 \pm 1.1 \\
101.0 \pm 2.3 \\
98.6 \pm 2.3\end{array}$ & $\begin{array}{c}98.8 \pm 1.7^{*} \\
101.0 \pm 1.5 \\
98.0 \pm 1.8\end{array}$ & $\begin{array}{r}99.3 \pm 2.1 \\
98.3 \pm 4.8 \\
105.1 \pm 3.6\end{array}$ & $\begin{array}{r}107.8 \pm 3.0 \\
98.4 \pm 3.5 \\
106.0 \pm 2.1\end{array}$ & $\begin{array}{l}116.0 \pm 2.0^{\#} \\
105.1 \pm 1.8 \\
110.3 \pm 4.0^{*}\end{array}$ \\
\hline LVEDP & $\begin{array}{c}7_{\text {inf. }}^{\prime} \\
5^{\prime}{ }_{\text {post. }} \\
15^{\prime}\end{array}$ & $\begin{array}{r}112.8 \pm 4.7 \\
100.7 \pm 8.1 \\
92.4 \pm 5.4\end{array}$ & $\begin{array}{l}104.6 \pm 4.4 \\
103.7 \pm 5.2 \\
106.8 \pm 6.5\end{array}$ & $\begin{array}{r}89.9 \pm 9.8 * \\
79.6 \pm 11.6 \\
101.0 \pm 13.3\end{array}$ & $\begin{array}{l}83.0 \pm 5.5^{\#} \\
76.8 \pm 5.4 \\
84.6 \pm 5.3\end{array}$ & $\begin{array}{l}87.1 \pm 5.6^{*} \\
72.9 \pm 6.8^{*} \\
84.9 \pm 6.5\end{array}$ \\
\hline $\mathrm{AoP}_{\mathrm{m}}$ & $\begin{array}{c}7^{\prime} \text { inf. } \\
5^{\prime} \text { post. } \\
15_{\text {post. }}^{\prime}\end{array}$ & $\begin{array}{r}109.6 \pm 3.3 \\
104.3 \pm 3.8 \\
97.3 \pm 3.7\end{array}$ & $\begin{array}{c}88.7 \pm 3.0^{*} \\
105.1 \pm 4.5 \\
101.2 \pm 3.9\end{array}$ & $\begin{array}{l}108.7 \pm 5.7 \\
115.2 \pm 10.3 \\
124.4 \pm 6.0^{*}\end{array}$ & $\begin{array}{l}139.2 \pm 6.0^{\#} \\
118.1 \pm 5.8 \\
142.2 \pm 3.3^{\#}\end{array}$ & $\begin{array}{l}152.0 \pm 8.5^{\#} \\
130.6 \pm 7.4^{*} \\
164.8 \pm 13.0^{\#}\end{array}$ \\
\hline $\mathrm{dP} / \mathrm{dt}_{\max }$ & $\begin{array}{c}7_{\text {inf. }}^{\prime} \\
5^{\prime}{ }_{\text {post. }} \\
15_{\text {post. }}^{\prime}\end{array}$ & $\begin{array}{r}107.6 \pm 1.4 \\
100.7 \pm 2.9 \\
97.1 \pm 3.1\end{array}$ & $\begin{array}{r}97.6 \pm 3.1 \\
102.7 \pm 2.8 \\
100.1 \pm 2.9\end{array}$ & $\begin{array}{l}101.2 \pm 3.3 \\
100.2 \pm 5.1 \\
106.1 \pm 6.0\end{array}$ & $\begin{array}{r}112.7 \pm 5.0 \\
95.5 \pm 3.8 \\
107.8 \pm 4.4\end{array}$ & $\begin{array}{l}127.5 \pm 5.4^{*} \\
106.1 \pm 6.7 \\
115.9 \pm 7.2^{*}\end{array}$ \\
\hline HR & $\begin{array}{c}7^{\prime} \text { inf. } \\
5^{\prime} \text { post. } \\
15^{\prime} \text { post. }\end{array}$ & $\begin{array}{r}100.8 \pm 1.6 \\
101.5 \pm 1.7 \\
98.8 \pm 2.8\end{array}$ & $\begin{array}{l}97.4 \pm 2.2 \\
97.7 \pm 2.5 \\
95.6 \pm 2.4\end{array}$ & $\begin{array}{r}99.8 \pm 1.2 \\
99.1 \pm 2.6 \\
101.8 \pm 3.6\end{array}$ & $\begin{array}{r}100.6 \pm 3.8 \\
96.4 \pm 4.3 \\
95.9 \pm 4.6\end{array}$ & $\begin{array}{r}104.5 \pm 3.1 \\
104.6 \pm 4.2 \\
95.6 \pm 2.9\end{array}$ \\
\hline $\mathrm{CO}$ & $\begin{array}{c}7_{\text {inf. }}^{\prime} \\
5^{\prime} \text { post. } \\
15_{\text {post. }}^{\prime}\end{array}$ & $\begin{array}{r}121.5 \pm 5.6 \\
108.7 \pm 2.7 \\
91.7 \pm 2.9\end{array}$ & $\begin{array}{l}92.1 \pm 4.0^{\#} \\
89.0 \pm 4.9^{\#} \\
83.6 \pm 3.9\end{array}$ & $\begin{array}{l}77.0 \pm 4.8^{\#} \\
67.1 \pm 5.6^{\#} \\
81.3 \pm 5.2\end{array}$ & $\begin{array}{l}60.2 \pm 3.6^{\#} \\
40.1 \pm 3.3^{\#} \\
53.1 \pm 5.4^{\#}\end{array}$ & $\begin{array}{l}50.0 \pm 3.5^{\#} \\
29.5 \pm 2.7^{\#} \\
37.4 \pm 3.7^{\#}\end{array}$ \\
\hline LVEDV & $\begin{array}{c}7_{\text {inf. }}^{\prime} \\
5_{\text {post }}^{\prime} \\
15_{\text {post }}^{\prime}\end{array}$ & $\begin{array}{r}104.7 \pm 1.9 \\
99.5 \pm 3.4 \\
96.3 \pm 2.4\end{array}$ & $\begin{array}{l}101.1 \pm 1.6 \\
100.3 \pm 1.8 \\
101.6 \pm 2.1\end{array}$ & $\begin{array}{l}94.3 \pm 4.5^{*} \\
88.8 \pm 6.2 \\
98.6 \pm 5.1\end{array}$ & $\begin{array}{l}92.8 \pm 2.6^{\#} \\
90.7 \pm 2.6 \\
93.8 \pm 2.5\end{array}$ & $\begin{array}{l}95.1 \pm 2.1 \\
89.3 \pm 3.1 \\
93.5 \pm 3.2\end{array}$ \\
\hline peak LVSP & $\begin{array}{r}5^{\prime} \text { post. } \\
15_{\text {post }}^{\prime} .\end{array}$ & $\begin{array}{l}98.7 \pm 1.3 \\
96.8 \pm 1.6\end{array}$ & $\begin{array}{l}94.6 \pm 1.7 \\
93.0 \pm 3.2\end{array}$ & $\begin{array}{l}96.5 \pm 3.5 \\
94.2 \pm 3.9\end{array}$ & $\begin{array}{l}104.1 \pm 2.1 \\
100.2 \pm 1.8\end{array}$ & $\begin{array}{l}104.0 \pm 2.2 \\
100.0 \pm 1.9\end{array}$ \\
\hline peak $\mathrm{dP} / \mathrm{dt}_{\max }$ & $\begin{array}{l}5^{\prime} \\
15_{\text {post. }}^{\prime}\end{array}$ & $\begin{array}{l}98.4 \pm 2.6 \\
96.1 \pm 1.5\end{array}$ & $\begin{array}{l}93.4 \pm 2.4 \\
93.1 \pm 2.7\end{array}$ & $\begin{array}{l}94.0 \pm 5.3 \\
89.9 \pm 4.9\end{array}$ & $\begin{array}{l}97.5 \pm 2.5 \\
93.2 \pm 2.6\end{array}$ & $\begin{array}{r}111.6 \pm 5.4 \\
98.7 \pm 3.3\end{array}$ \\
\hline $\mathrm{n}$ & & 10 & 10 & 9 & 10 & 10 \\
\hline
\end{tabular}

LVSP, left ventricular systolic pressure; LVEDP, left ventricular end-diastolic pressure; AoP $\mathrm{m}_{\mathrm{m}}$, mean aortic pressure; $\mathrm{dP} / \mathrm{dt}_{\max } ; \mathrm{HR}$, heart rate; $\mathrm{CO}$, cardiac output; LVEDV, left ventricular end-diastolic volume; peak LVSP and peak $\mathrm{dP} / \mathrm{dt}_{\text {max }}$, data derived from isovolumic maximum beat; $7^{\prime}{ }_{\text {inf. }}$, at termination of infusion; $5_{\text {post. }}^{\prime}$ and $15^{\prime}$ post. 5 and 15 min after infusion.

Values are means \pm SEM in percentage of preinfusion values. $*=p<0.05,{ }^{*}=p<0.01$. 
and $15 \mathrm{~min}$ postinfusion. At termination of infusion and 5 and $15 \mathrm{~min}$ postinfusion isovolumic measurements were carried out. At the end of the hemodynamic measurements, blood samples were drawn from the aorta for determination of plasma endothelin-1 levels with a radioimmunoassay (Endothelin-1,2 (high sensitivity) [ $\left.{ }^{125} \mathrm{I}\right]$ assay system, Amersham International plc, Amersham, UK).

All data are means \pm SEM. Hemodynamic data were normalized to the individual preinfusion control data (100\%; absolute preinfusion control data see Table 1). Normalized data from the endothelin- 1 infusion groups were compared with those of the control group by analysis of variance followed by a Dunnett test (6); $p<0.05$ was accepted as significant.

\section{Results}

The four animals which received $10000 \mathrm{ng}$ ET-1/kg died a short time after infusion: three animals developed low output failure, the other one died due to ventricular fibrillation.

\section{Auxotonic measurements in the intact circulation}

The results of the hemodynamic measurements in the intact circulation are shown in Table 2. During the endothelin-infusion the left ventricular systolic pressure transiently decreases (2nd minute of infusion: $\mathrm{NaCl}: 101.8 \pm 0.5 \%$ vs. $500 \mathrm{ng} \mathrm{ET}-1 / \mathrm{kg}$ : $97.3 \pm 1.5 \% ; 1000 \mathrm{ng}$ ET-1/kg: $95.9 \pm 2.1 \% ; 2500 \mathrm{ng} \mathrm{ET}-1 / \mathrm{kg}: 93.9 \pm 2.3 \%, \mathrm{p}<0.05$

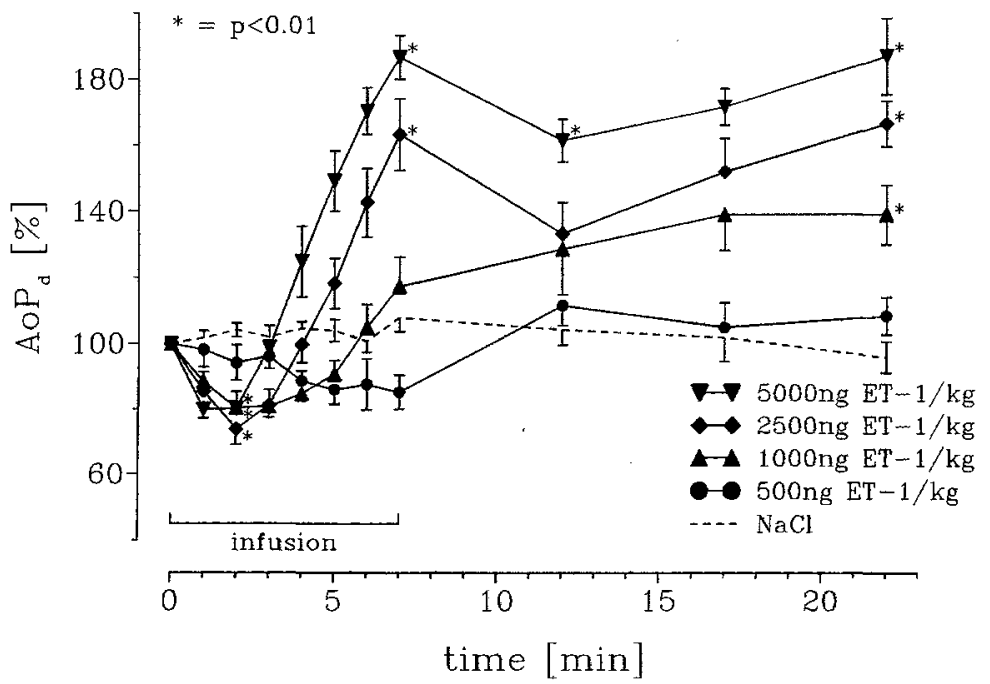

Fig. 1. Effects of different doses of endothelin 1 on the diastolic aortic pressure in the intact circulation. $1 \mathrm{ml} \mathrm{NaCl}(\mathrm{n}=10)$; endothelin-1: $500 \mathrm{ng} / \mathrm{kg}$ (closed circles, $\mathrm{n}=10$ ), $1000 \mathrm{ng} / \mathrm{kg}$ (closed triangles, $\mathrm{n}=9$ ), $2500 \mathrm{ng} / \mathrm{kg}$ (closed diamonds, $\mathrm{n}=10$ ), $5000 \mathrm{ng} / \mathrm{kg}$ (closed inverted triangles, $\mathrm{n}=10$ ); means $\pm S E M$ in percentage of preinfusion values; ${ }^{*}=\mathrm{p}<0.01$. 


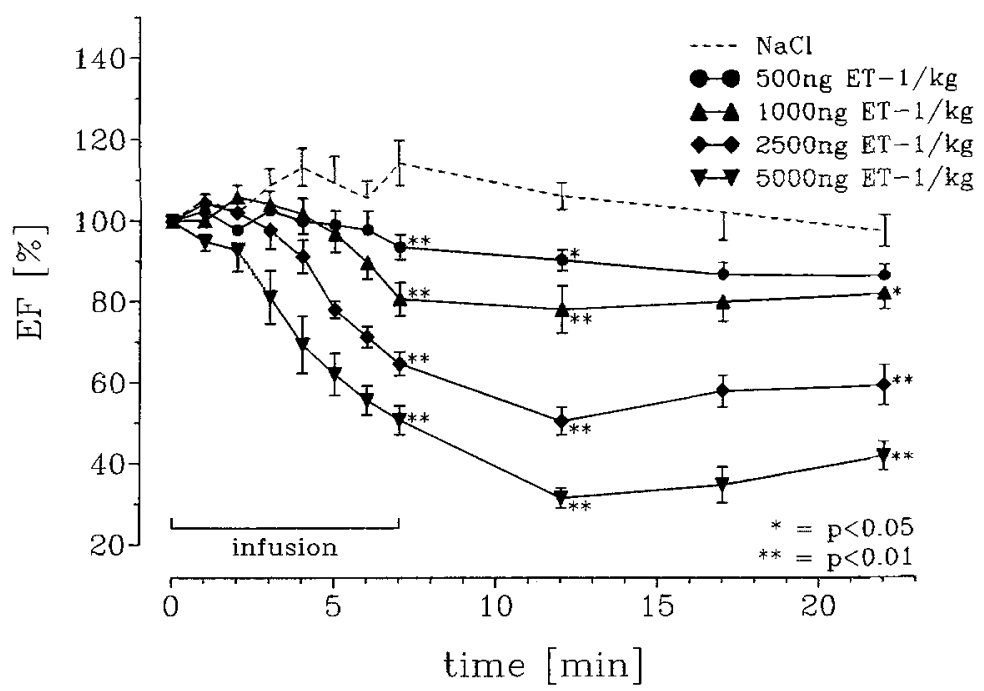

Fig. 2. Effects of different doses of endothelin-1 on the ejection fraction in the intact circulation. $1 \mathrm{ml}$ $\mathrm{NaCl}(\mathrm{n}=10)$; endothelin- $1: 500 \mathrm{ng} / \mathrm{kg}$ (closed circles, $\mathrm{n}=10), 1000 \mathrm{ng} / \mathrm{kg}$ (closed triangles, $\mathrm{n}=9$ ), 2500 $\mathrm{ng} / \mathrm{kg}$ (closed diamonds, $\mathrm{n}=10$ ), $5000 \mathrm{ng} / \mathrm{kg}$ (closed inverted triangles, $\mathrm{n}=10$ ); means \pm SEM in percentage of preinfusion values; $*=p<0.05,{ }^{* * *}=p<0.01$.

$5000 \mathrm{ng}$ ET-1/kg: $90.2 \pm 3.4 \%, \mathrm{p}<0.01$ ). Then the left ventricular systolic pressure rises dose-dependently. At the end of infusion the LVSP is still slightly but significantly reduced in the $500 \mathrm{ng} / \mathrm{kg}$-group and significantly elevated in the $5000 \mathrm{ng} / \mathrm{kg}$-group. The

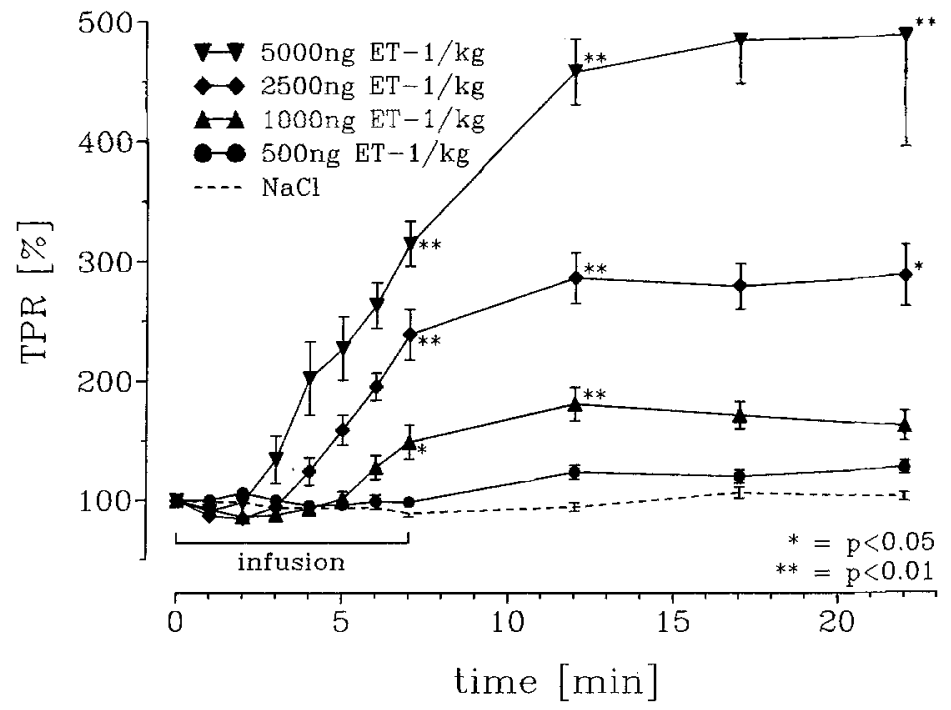

Fig. 3. Effects of different doses of endothelin-1 on the total peripheral resistance in the intact circulation. $1 \mathrm{ml} \mathrm{NaCl}(\mathrm{n}=10)$; endothelin-1: $500 \mathrm{ng} / \mathrm{kg}$ (closed circles, $\mathrm{n}=10), 1000 \mathrm{ng} / \mathrm{kg}$ (closed triangles, $\mathrm{n}=9$ ), $2500 \mathrm{ng} / \mathrm{kg}$ (closed diamonds, $\mathrm{n}=10$ ), $5000 \mathrm{ng} / \mathrm{kg}$ (closed inverted triangles, $\mathrm{n}=10$ ); means \pm SEM in percentage of preinfusion values; $*=p<0.05, * *=p<0.01$. 


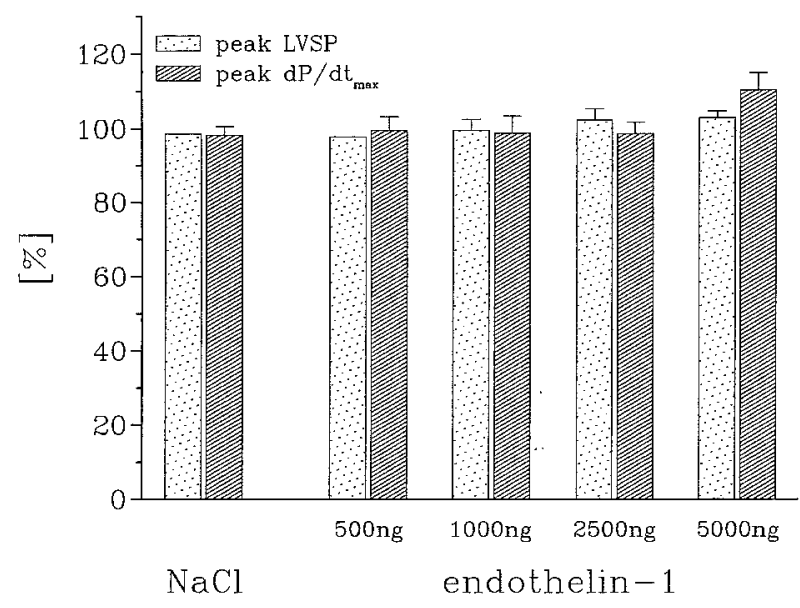

Fig. 4. Peak isovolumic left ventricular systolic pressure (peak LVSP) and the corresponding peak isovolumic $\mathrm{dP} / \mathrm{dt}_{\max }$ (peak $\mathrm{dP} / \mathrm{dt}_{\max }$ ) at the end of infusion; means $\pm S E M$ in percentage of preinfusion values.

initial fall and the following dose-related increase is more pronounced for the mean and the diastolic aortic pressure, reflecting the peripheral vascular effects of endothelin-1. The fall of the diastolic aortic pressure at the beginning of infusion is even significant in the higher doses (Fig. 1). The decrease is followed by a rise, which is earlier and more pronounced in higher doses of endothelin-1. This increase persists until the end of the experiments. $\mathrm{dP} / \mathrm{dt}_{\max }$ shows the same changes as the pressures.

The heart rate is not influenced by endothelin-1. As a result of the dose-dependent decrease of the stroke volume (end of infusion: $\mathrm{NaCl}: 119.9 \pm 5.8 \%$ vs. $500 \mathrm{ng} \mathrm{ET}-1$ /

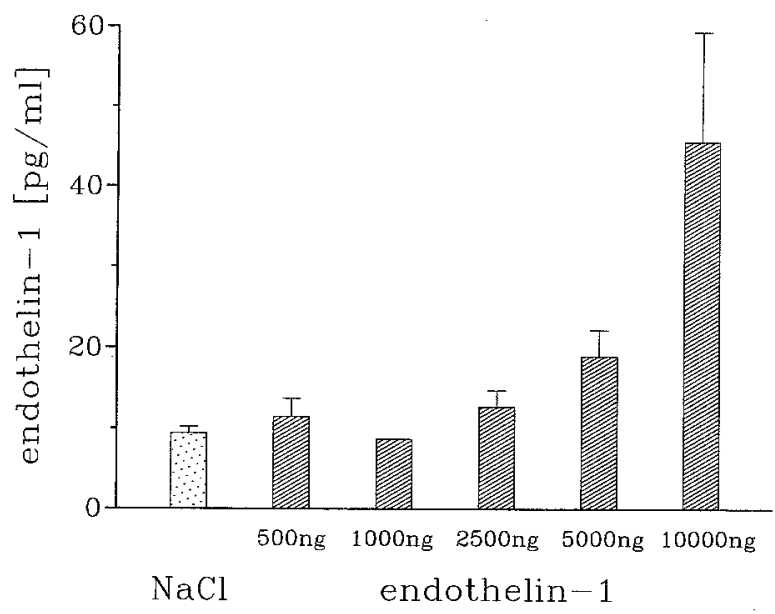

Fig. 5. Venous plasma levels of endothelin- 1 at the end of the experiments. $1 \mathrm{ml} \mathrm{NaCl}(\mathrm{n}=4)$; endothelin-1: $500 \mathrm{ng} / \mathrm{kg}(\mathrm{n}=4), 1000 \mathrm{ng} / \mathrm{kg}(\mathrm{n}=8), 2500 \mathrm{ng} / \mathrm{kg}(\mathrm{n}=10), 5000 \mathrm{ng} / \mathrm{kg}(\mathrm{n}=10), 10000 \mathrm{ng} /$ $\mathrm{kg}(\mathrm{n}=4)$; means \pm SEM. 


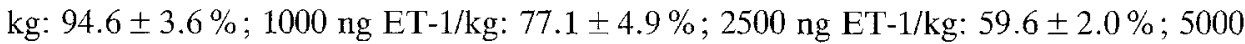
ng ET-1/kg: $48.0 \pm 3.2 \%$; all $\mathrm{p}<0.01$ ), the cardiac output is reduced significantly in all endothelin-1 groups until $15 \mathrm{~min}$ after infusion. The ejection fraction is significantly lowered in all endothelin-1 groups (Fig. 2), and the left ventricular end-diastolic pressure and the corresponding end-diastolic volume are slightly reduced (Table 2).

After an initial vasodilatation (maximum in the 2 nd min of infusion) endothelin-1 markedly elevates the calculated total peripheral resistance (Fig. 3).

\section{Isovolumic measurements}

The dose-related effects of endothelin- 1 on the isovolumic registrations at the end of infusion are shown in Fig. 4. The peak of the isovolumic left ventricular systolic pressure is not changed under increasing doses of endothelin-1. The little increase of the peak isovolumic $\mathrm{dP} / \mathrm{dt}_{\max }$ in the 1000 - and $5000 \mathrm{ng} \mathrm{ET}-1 / \mathrm{kg}$-group is also not significant. Five and $15 \mathrm{~min}$ later these two indices of myocardial contractility are also not altered by endothelin-1 (Table 2).

\section{Plasma endothelin-1 levels}

The venous plasma levels of endothelin- 1 at the end of the experiments are illustrated in Fig. 5. There is a dose-related increase of the plasma endothelin-1 levels (data after $10000 \mathrm{ng}$ ET-1/kg were obtained directly after the heart has stopped beating in these animals).

\section{Discussion}

Endothelin-1 has a potent, dose-dependent contractile effect on vascular smooth muscle (34). Conflicting results are published about the inotropic effects of endothelin1. In vitro experiments showed a positive inotropic effect of endothelin- 1 in animal (12, $14,17,22,26,37)$ and human (26) cardiac tissues. Atrial muscle is more sensitive than ventricular muscle (26). But these experiments avoided changes of the myocardial perfusion. Experiments in isolated hearts could not detect a positive inotropic effect of endothelin-1 $(16,27)$.

In vivo experiments even described a negative inotropic effect of endothelin-1 (5, 39). As endothelin- 1 also has a coronary constrictive effect $(3,7,23,25)$ and may cause electrocardiographic signs of myocardial ischemia $(5,25)$ it is of importance to determine the inotropic effects of endothelin-1 on hearts with an intact regulation of the coronary perfusion. We used an in vivo model which allows (besides making hemodynamic measurements in the intact circulation) the determination of the left ventricular pressure generating capacity as a well-established method to assess myocardial contractility independent of peripheral vascular effects (28) but dependent on changes of the coronary perfusion. To investigate the dose-dependent hemodynamic and inotropic effects of endothelin-1 we administered increasing doses of endothelin-1. Although endothelin-1 has a rather high first-pass effect (1) the plasma-endothelin levels at the end of the experiments indicate that there is also a dose-dependent rise of endothelin-1 in the myocardium.

In our experiments endothelin-1 produces a biphasic blood pressure response. The initial transient hypotension and the following dose-dependent sustained hypertensive response confirm the results of other in vivo studies $(9,19,20,25,30,39)$. This biphasic 
response is mostly pronounced in the diastolic aortic pressure, reflecting the peripheral vascular effects of endothelin-1. As the cardiac output remained unchanged during the early phase of endothelin-infusion, the reduction of blood pressure is primarily due to a transient vasodilatation. This short-lived vasodilatatory response of endothelin-1 (19, $27,30,39)$ may be explained by the fact that endothelin- 1 induces the release of vasodilatatory mediators like endothelium-derived relaxing factor (EDRF) $(4,31,36)$, prostacyclin $(4,29)$ and atrial natriuretic peptide (ANP) (8). The following dosedependent and sustained endothelin-induced vasoconstriction is in accordance to other in vivo studies. While Yang et al. (39) observed an increase of the LVEDP and Garcia et al. (9) could not detect a change of the LVEDP after endothelin-1, our experiments show an endothelin-induced reduction of the LVEDP. Endothelin-1 may decrease venous return due to reduction of plasma volume by a loss of plasma water to the interstitium (18) or due to a vasoconstriction in the splanchnic vascular bed (24).

In our experiments endothelin-doses up to $5000 \mathrm{ng}$ ET-1/kg have no effect on the heart rate. This data confirm the results of other in vivo studies $(5,20,39)$. Ishikawa et al. (13) detected a positive chronotropic response of endothelin-1 in guinea pig spontaneously beating right atrial preparation. In vivo studies of Mir et al. (25) described a positive chronotropic effect by lower doses of endothelin-1 and a hypoxiainduced bradycardia by higher doses of endothelin-1. Indeed, in the animals which received the lethal dose of $10000 \mathrm{ng} E T-1 / \mathrm{kg}$ the heart rate was also reduced (end of infusion: $\mathrm{NaCl}: 100.8 \pm 1.6 \%$ vs. $10000 \mathrm{ng} \mathrm{ET}-1 / \mathrm{kg}$ : $71.9 \pm 6.9 \%, \mathrm{p}<0.01$ ).

The reduction of the cardiac output in our experiments may be explained in part by the decrease of the preload and the increase of the afterload. Yang et al. (39) supposed that the endothelin-induced fall of $\mathrm{CO}$ can be explained in part by a direct depressant effect on cardiac contractility. They supported this hypothesis by the fact that $\mathrm{dP} / \mathrm{dt}$ max was also reduced in their in-vivo experiments. In contrast to that, Kitayoshi et al. (20) and Garcia et al. (9) measured an endothelin-induced increase of $\mathrm{dP} / \mathrm{dt}_{\max }$ and they concluded that endothelin-1 has a positive inotropic effect. We also measured a

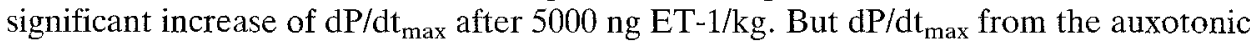
beating heart may be influenced by the pre- and afterload (32). As endothelin-1 has such a tremendous effect on pre- and afterload, it was an important part of our study to determine the peak of the isovolumic LVSP and the corresponding $\mathrm{dP} / \mathrm{dt}_{\max }$ as indexes of myocardial contractility independent of these effects. The results of the isovolumic measurements do not indicate a positive inotropic effect of endothelin- 1 detectable in our in vivo model. Endothelin-1 has a strong and dose-dependent coronary constrictive effect (16). So it may be possible that the direct positive inotropic effect of endothelin1 , which is detectable in in vitro studies, is counterbalanced in vivo by an indirect negative inotropic effect due to the coronary constrictive effect of endothelin- 1 . This has also been suggested previously by us in a review of myocardial actions of endothelin (21) and can also be derived from experiments in isolated hearts, in which the coronary flow decreased due to endothelin-1 $(16,27)$.

References

1. Anggärd E, Galton S, Rae G, Thomas R, McLoughlin L, de Nucci G, Vane JR (1989) The fate of radioiodinated endothelin-1 and endothelin-3 in the rat. $J$ Cardiovasc Pharmacol 13 (Suppl. 5):\$46 9 
2. Baydoun AR, Peers SH, Cirino G, Woodward B (1989) Effects of endothelin-I on the rat isolated heart. J Cardiovasc Pharmacol 13 (Suppl 5):S193-6

3. Clozel JP, Clozel M (1989) Effects of endothelin on the coronary vascular bed in open chest dogs. Circ Res 65:1193-1200

4. De Nucci $G$, Thomas R, D'Orleans-Juste $P$, et al (1988) Pressor effects of circulating endothelin are limited by its removal in the pulmonary circulation and by the release of prostacyclin and endotheiium-derived relaxing factor. Proc Natl Acad Sci USA 85:9797-800

5. Domenech R, Macho P, González R, Huidobro-Toro JP (1991) Effect of endothelin on total and regional coronary resistance and on myocardial contractility. Eur J Pharmacol 192:409-16

6. Dunnett CW (1955) A multiple comparison procedure for comparing several treatments with a control. J Amer Statist Assoc 50:1096-121

7. Fukuda K, Hori S, Kusuhara M (1989) Effect of endothelin as a coronary vasoconstrictor in the Langendorff-perfused rat heart. Eur J Pharmacol 165:301-4

8. Fukuda Y, Hirata Y, Yoshimi H, et al (1988) Endothelin is a potent secretagogue for atrial natriuretic peptide in cultured rat atrial myocytes. Biochem Biophys Res Commun 155:167-72

9. Garcia R, Lachance D, Thibault G (1990) Positive inotropic action, natriuresis and atrial natriuretic factor release induced by endothelin in the conscious rat. J Hypertens 8:725-31

10. Hirata Y, Fukuda Y, Yoshima H, Emori T, Shichira M, Marumo F (1989) Specific receptors for endothelin in cultured rat cardiocytes. Biochem Biophys Res Commun 160:1438-44

11. Hoffmeister HM, Betz R, Fiechtner H, Seipel L (1987) Myocardial and circulatory effects of inosine. Cardiovasc Res 21:65-71

12. Hu JR, von Harsdorf R, Lang RE (1988) Endothelin has potent inotropic effects in rat atria. Eur J Pharmacol 158:275-8

13. Ishikawa T, Yanagisawa M, Kimura S, Goto K, Masaki T (1988) Positive chronotropic effects of endothelin, a novel endothelium-derived vasoconstrictor peptide. Pflügers Arch 413:109-10

14. Ishikawa T, Yanagisawa M, Kimura S, Goto K, Masaki T (1988) Positive inotropic action of novel vasoconstrictor peptide endothelin on guinea pig atria. Am J Physiol 255:H970-3

15. Kai H, Kanaide $\mathrm{H}$, Nakamura M (1989) Endothelin-sensitive intracellular $\mathrm{Ca}^{2+}$ store overlaps with caffeine-sensitive one in rat aortic smooth muscle cells in primary culture. Biochem Biophys Res Commun 158:235-43

16. Karwatowska-Prokopczuk E, Wennmalm $\AA$ (1990) Effects of endothelin on coronary flow, mechanical performance, oxygen uptake, and formation of purines and on outflow of prostacyclin in the isolated rabbit heart. Circ Res 66:46-54

17. Kelly RA, Eid H, Krämer BK, O'Neill M, Liang BT, Reers M, Smith TW (1990) Endothelin enhances the contractile responsiveness of adult rat ventricular myocytes to calcium by a pertussis toxin-sensitive pathway. J Clin Invest 86:1164-71

18. King AJ, Brenner BM, Anderson S (1989) Endothelin: a potent renal and systemic vasoconstrictor peptide. Am J Physiol 256:F1051-8

19. King AJ, Pfeffer JM, Pfeffer MA, Brenner BM (1990) Systemic hemodynamic effects of endothelin in rats. Am J Physiol 258:H787-92

20. Kitayoshi T, Watanabe T, Shimamoto N (1989) Cardiovascular effects of endothelin in dogs: positive inotropic action in vivo. Eur J Pharmacol 166:519-22

21. Krämer BK, Nishida M, Kelly RA, Smith TW (1992) Endothelins: myocardial actions of a new class of cytokines. Circulation 85:350-6

22. Krämer BK, Smith TW, Kelly RA (1991) Endothelin and increased contractility in adult rat ventricular myocytes: role of intracellular alkalosis induced by activation of the protein kinase C-dependent $\mathrm{Na}^{+}-\mathrm{H}^{+}$exchanger. Circ Res 86:269-79

23. Kurihara H, Yamaoki K, Nagai R, et al. (1989) Coronary vasoconstriction produced by endothelin, a novel endothelium-derived vasoconstrictor peptide. Circulation 78 (Suppl II): 171

24. Madeddu P, Troffa C, Glorioso N, et al. (1989) Effect of endothelin on regional hemodynamics and renal function in awake normotensive rats. J Cardiovasc Pharmacol 14:818-25

25. Mir AK, Berthold H, Scholtysik GE, Fozard JR (1989) Cardiovascular effects of endothelin-1 in pithed spontaneously hypertensive rats: evaluation of its mechanism(s) of action. NaunynSchmiedeberg's Arch Pharmacol 340:424-30 
26. Moravec CS, Reynolds EE, Stewart RW, Bond M (1989) Endothelin is a positive inotropic agent in human and rat heart in vitro. Biochem Biophys Res Commun 159:14-8

27. Neubauer S, Ertl G, Haas U, Pulzer F, Kochsiek K (1990) Effects of endothelin-1 in isolated perfused rat heart. J Cardiovasc Pharmacol 16:1-8

28. Pfeffer MA, Pfeffer JM (1985) Left ventricular hypertrophy and pressure generating capacity in aging genetically hypertensive rats. J Cardiovase Pharmacol 7:41-5

29. Rae GA, Trybulec M, de Nucci G, Vane JR (1989) Endothelin-1 releases eicosanoids from rabbit isolated perfused kidney and spleen. J Cardiovasc Pharmacol (Suppl 5):S89-92

30. Rohmeiss P, Photiadis J, Rohmeiss S, Unger T (1990) Hemodynamic actions of intravenous endothelin in rats: comparison with sodium nitroprusside and methoxamine. Am J Physiol 258:H337-46

31. Schini VB, Kim ND, Vanhoutte PM (1991) The basal and stimulated release of EDRF inhibits the contractions evoked by endothelin- 1 and endothelin- 3 in aortae of normotensive and spontaneously hypertensive rats. J Cardiovase Pharmacol 17 (Suppl 7):S267-71

32. Schmidt HD, Scheer RD (1981) Quantitative data on the afterload dependence of left ventricular $\mathrm{dP} / \mathrm{dt}_{\max }$ in isolated canine hearts. Basic Res Cardiol 76:89-105

33. Simonson MS, Wann S, Mene P, et al (1989) Endothelin stimulates phospholipase $\mathrm{C} \mathrm{Na}^{+}-\mathrm{H}^{+}$ exchange, C-fos expression, and mitogenesis in rat mesangial cells. J Clin Invest 83:708-12

34. Van Renterghem C, Vigne P, Barhanin J, Schmid-Alliana A, Frelin C, Lazdunski M (1988) Molecular mechanisms of action of the vasoconstrictor peptide, endothelin. Biochem Biophys Res Commun 157:977-85

35. Wallnofer A, Weir S, Rüegg U, Cauvin C (1989) The mechanism of action of endothelin-1 as compared with other agonists in vascular smooth muscle. J Cardiovasc Pharmacol 13 (Suppl 5): S23-31

36. Warner T, de Nucci G, Vane JR (1988) Release of EDRF by endothelin in the rat isolated perfused mesentery. Brit J Pharmacol 95:723P

37. Watanabe T, Kusomoto K, Kitayoshi T, Shimamoto N (1989) Positive inotropic and vasoconstrictive effects of endothelin- 1 in in vivo and in vitro experiments: characteristics and the role of the L-type calcium channels. J Cardiovasc Pharmacol 13 (Supp1 5):S108-11

38. Yanagisawa M, Kurihara H, Kimura S, et al (1988) A novel potent constrictor peptide produced by vascular endothelial cells. Nature (Lond) 332:411-5

39. Yang X-P, Madeddu P, Micheletti R, et al (1991) Effects of intravenous endothelin on hemodynamics and cardiac contractility in conscious Milan normotensive rats. J Cardiovase Pharmacol $17: 662-9$

Received July 30, 1993 revision accepted October 20, 1993

Authors' address:

Dr. M. E. Beyer, Medizinische Universitätsklinik, Abt. III, Otfried-Müller-Straße 10, 72076 Tübingen, FRG 